\title{
Congenital perineal lipoma: an unusual presentation
}

\author{
Isabel Rosário Periquito, ${ }^{1}$ Célia Iglésias Neves, ${ }^{2}$ Filipe Catela Mota, ${ }^{3}$ Teresa Tomé ${ }^{2}$
}

${ }^{1}$ Department of Pediatrics, Centro Hospitalar de Setúbal, Setúbal, Portugal

${ }^{2}$ Department of Pediatrics, Maternidade Dr Alfredo da Costa, Lisboa, Portugal ${ }^{3}$ Department of Pediatric Surgery, Hospital D Estefânia, Lisboa, Portugal

\section{Correspondence to}

Dr Isabel Rosário Periquito, isabelperiquito@gmail.com

Accepted 16 April 2014

\section{(1) ciossank}

To cite: Periquito $\mathrm{IR}$, Neves Cl, Mota FC, et al. BMJ Case Rep Published online: [please include Day Month Year] doi:10.1136/ bcr-2013-203495

\section{DESCRIPTION}

We report a case of a male newborn, the second of triplets, from non-consanguineous parents who conceived using in vitro fertilisation. It was an uneventful pregnancy and ultrasounds were normal revealing a

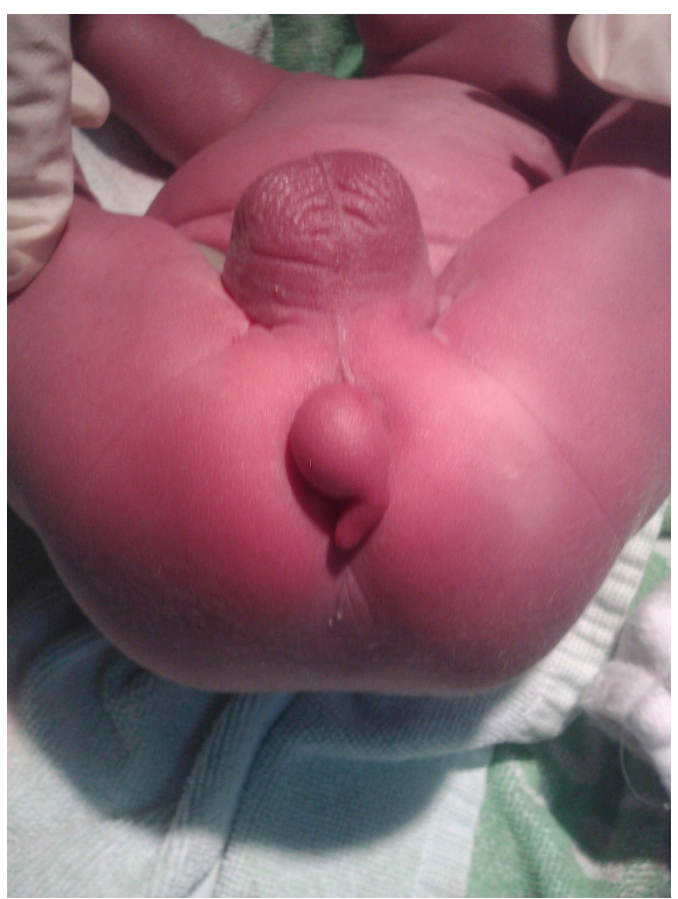

Figure 1 Neonate with a spherical pedunculated mass in the perianal region, with $13.8 \mathrm{~mm}$ of greater axis, with a cylindrical $5 \mathrm{~mm}$ form attached.

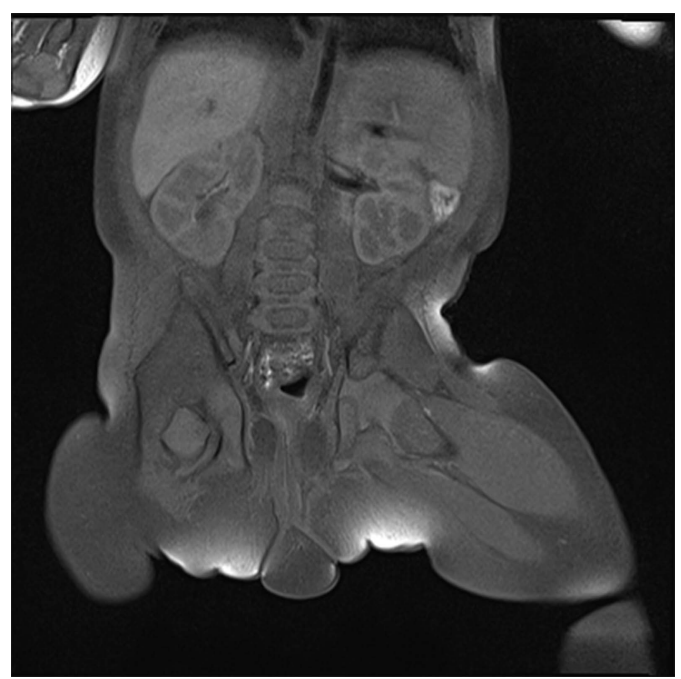

Figure 2 MRI showing an extrinsic structure, predominantly composed of adipose tissue with a cystic component, with an internal fibrous tissue extension to the perianal region.

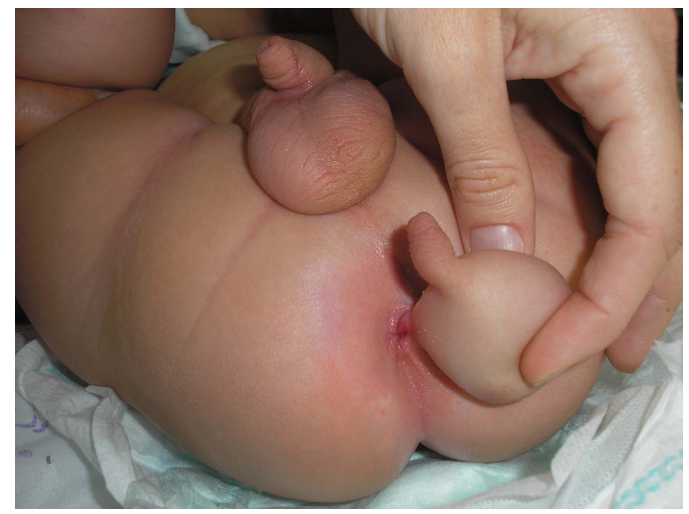

Figure 3 Spherical pedunculated mass in the perianal region, at the age of 6 months.

dichorionic triamniotic pregnancy. A caesarean section was performed at 34 weeks of gestation. The Apgar score was 9/10, weight $2425 \mathrm{~g}$ and physical examination revealed a congenital malformation in the perianal region with $13.8 \mathrm{~mm}$ of greater axis, spherical pedunculated and soft, with a cylindrical $5 \mathrm{~mm}$ form attached, similar to an accessory penis and scrotum (figure 1).

The neonate underwent an ultrasound displaying normal structures with an external malformation consistent with an accessory testicle, while MRI showed a complex structure, compatible with type I sacrococcygeal teratoma (figure 2). At 6 months of age (figure 3 ), the mass was locally excised, without complications. Postoperative histological examination however, revealed a subcutaneous lipoma.

Isolated congenital perineal lipomas are rare lesions that can lead to a misdiagnosis of an accessory scrotum in men, in particular because these two conditions can be associated in over $80 \%$ of cases. ${ }^{12}$ The differential diagnosis is mainly an accessory scrotum, sacrococcygeal teratoma, fetus in fetu, haemangioma, haemartoma or lipoblastoma. ${ }^{2}$ A complete evaluation of the urogenital and anorectal tract is recommended, taking into account related anomalies described such as renal agenesis, anorectal malformations, scrotum and penile anomalies. ${ }^{1-3}$ These isolated lesions are usually benign and the standard treatment is local excision. ${ }^{2}$

\section{Learning points}

- Congenital perineal lipomas are rare benign lesions, but may be associated with an accessory scrotum ( $>80 \%$ of cases).

- A complete evaluation of the urogenital and anorectal tract is recommended because of associated anomalies. 
Contributors IRP was involved in data acquisition and drafting of the manuscript. CIN participated in the drafting, revising and conception of the manuscript. FCM and TT participated in revising the manuscript.

Competing interests None.

Patient consent Obtained.

Provenance and peer review Not commissioned; externally peer reviewed.

\section{REFERENCES}

1 Park $\mathrm{KH}$, Hong JH. Perineal lipoma in association with scrotal anomalies in children. BJU Int 2006;98:409-12.

2 Wax JR, Pinette MG, Mallory $B$, et al. Prenatal sonographic diagnosis of a perineal lipoma. J Ultrasound Med 2010;29:1257-9.

3 Wester T, Rintala R. Perineal lipomas associated with anorectal malformations. Pediatr Surg Int 2006;22:979-81.

Copyright 2014 BMJ Publishing Group. All rights reserved. For permission to reuse any of this content visit http://group.bmj.com/group/rights-licensing/permissions.

BMJ Case Report Fellows may re-use this article for personal use and teaching without any further permission.

Become a Fellow of BMJ Case Reports today and you can:

- Submit as many cases as you like

- Enjoy fast sympathetic peer review and rapid publication of accepted articles

- Access all the published articles

- Re-use any of the published material for personal use and teaching without further permission

For information on Institutional Fellowships contact consortiasales@bmjgroup.com

Visit casereports.bmj.com for more articles like this and to become a Fellow 